\title{
Karakteristik Morfometrik Ayam Kampung Jantan dan Betina di Desa Tirtomulyo Kecamatan Plantungan, Kabupaten Kendal, Jawa Tengah
}

\section{Morphometrical characteristics of male and female native chickens in Tirtomulyo Village, Plantungan sub-district, Kendal districts, Central Java}

\author{
A. N. N. Permadi*, E. Kurnianto, dan Sutiyono \\ Fakultas Peternakan dan Pertanian Universitas Diponegoro, Semarang - Indonesia \\ *Corresponding E-mail: ajiknovian@gmail.com \\ (Diterima: 22 Agustus 2019; Disetujui: 18 November 2019)
}

\begin{abstract}
ABSTRAK
Penelitian ini bertujuan untuk menganalisis karakteristik morfometrik ayam kampung yang disukai dan tidak disukai di Desa Tirtomulyo, Kecamatan Plantungan, Kabupaten Kendal, Jawa Tengah. Materi menggunakan 105 ekor ayam kampung yang terdiri dari 5 ekor jantan dan 100 ekor betina. 30 peternak sebagai responden untuk menentukan ayam disukai dan tidak disukai. Data dianalisis menggunakan uji t, Principal Component Analysis dengan menggunakan alat bantu Statistical Analysis System (SAS) University Edition. Hasil penelitian memperlihatkan bahwa ayam jantan memiliki perbedaan yang nyata $(\mathrm{P}<0,05)$ pada lingkar tarsometatarsus dan panjang sternum, sedangkan ayam betina memiliki perbedaan nyata $(\mathrm{P}<0,05)$ pada bobot badan dan tinggi jengger. Parameter pembeda pada ayam kampung jantan dan betina yang disukai dan tidak disukai adalah panjang sayap yaitu 0,619 dan 0,922 . Peta penyebaran ayam jantan dan betina yang disukai dan tidak disukai mempunyai ukuran tubuh yang lebih besar dibandingkan ayam jantan dan betina yang tidak disukai.
\end{abstract}

Kata kunci: ayam kampung disukai, ayam kampung tidak disukai, morfometrik, panjang sayap

\section{ABSTRACT}

The objective of this study was to analyze the morphometric characteristics of likes and dislikes native chickens in Tirtomulyo Village, Plantungan Sub-District, Kendal District, Central Java. The material used was 105 native chickens consisted of 5 males and 100 females. Thirty respondents were acted as to determine the likes and dislikes chickens. The data obtained were analyzed by t-test, Principal Component Analysis by using the University Edition of Statistical Analysis (SAS) System. The result showed that male chicken was significantly different $(P<0.05)$ in the circumference of tarsometatarsus and sternum length, while there female have significant differences $(P<0.05)$ in body weight and height comb. A distinguishing factor in sex likes and dislikes were the wing length of 0.619 and 0.922. Map of the spread for male and female chickens liked was preferred to have a larger body size than male and female chickens disliked.

Keywords: like native chickens, dislike native chickens, morphometric, wing length

\section{PENDAHULUAN}

Ayam kampung merupakan ayam yang mempunyai penyebaran sangat luas di seluruh wilayah Indonesia dan berpotensi baik untuk masa depan sebagai produksi daging dan telur yang dihasilkan untuk perkembangan peternakan di Indonesia. Pemeliharaannya yang mudah dan dapat digunakan sebagai usaha sampingan dan secara tradisional. Produktivitas ayam kampung yang dipelihara secara tradisional memiliki produksi yang rendah dan pertumbuhan yang lambat serta mortalitas yang tinggi.

Ayam kampung yang dipelihara di pedesaan memiliki produksi berkisar antara 
30-40 butir/tahun. Rendahnya produksi telur ayam kampung disebabkan terdapat proses mengeram dan mengasuh anak yang mencapai 107 hari (Suryana dan Hasbianto, 2008). Bobot badan ayam kampung rata-rata 324,75 dan 651 gram pada umur 4 dan 8 minggu, sedangkan pada ayam kampung dewasa memiliki bobot badan sebesar $1.404 \mathrm{~kg}$ (Rahayu et al., 2010). Ciri-ciri kualitatif pada warna bulu ayam kampung yang sangat bervariasi. Rasyaf (2011) menyatakan bahwa ayam jantan memiliki warna lurik kuning, warna hitam yang terdapat pada bulu punggung dan dada serta warna hitam kehijauan pada bulu ekor. Pada ayam kampung betina memiliki warna lurik abu-abu pada leher punggung dan sayap, bulu dada dan bulu ekor yang memiliki warna putih. Sifat kuantitatif dapat dilihat melalui pengukuran dalam bentuk morfometrik seperti panjang shank, tibia, femur, sternum dan panjang sayap (Sadarman et al., 2013). Ukuran morfometrik ayam dapat dimanfaatkan untuk proses perkawinan silang antar bangsa dan seleksi ayam (Ashifudin et al., 2017).

Masyarakat di Desa Tirtomulyo, Kecamatan Plantungan, Kabupaten Kendal salah satu masyarakat yang memelihara ayam kampung sebagai ternak penghasil telur konsumsi, telur tetas dan daging, tetapi ayam yang dipelihara belum mempunyai sifat kualitatif dan kuantitatif pada ayam kampung yang spesifik. Masyarakat memiliki motivasi dan kesenangan terhadap sifat-sifat tertentu yang disukai untuk pengembangan menjadi ayam kampung. Maka perlu adanya penelitian mengenai sifat kuantitatif dan sifat kualitatif yang spesifik dan unggul berdasarkan ayam kampung yang disukai dan tidak disukai oleh masyarakat.

Tujuan penelitian untuk mengetahui karakteristik morfometrik ayam kampung yang disukai dan yang tidak disukai masyarakat di Desa Tirtomulyo, Kecamatan Plantungan, Kabupaten Kendal. Manfaat dari penelitian memberikan informasi tentang karakteristik morfometrik ayam kampung di Desa Tirtomulyo, Kecamatan Plantungan,
Kabupaten Kendal.

Hipotesis penelitian ini adalah ayam kampung di Desa Tirtomulyo, Kecamatan Plantungan, Kabupaten Kendal memiliki ciri kualitatif yang bervariasi dan memiliki karakteristik morfometrik yang berbeda antara ayam jantan dan betina yang disukai dan tidak disukai oleh masyarakat yang dikembangbiakkan di Desa Tirtomulyo, Kecamatan Plantungan, Kabupaten Kendal.

\section{METODE}

Materi penelitian menggunakan 5 ekor ayam kampung jantan dan 100 ekor ayam kampung betina di Desa Tirtomulyo, Kecamatan Plantungan Kabupaten Kendal. Penelitian pendahuluan dilakukan dengan wawancara sebanyak 30 orang sebagai responden. Syarat materi ayam kampung yang digunakan adalah ayam yang sudah dewasa tubuh dan dewasa kelamin sehingga memiliki ciri ayam jantan sudah siap mengawini ayam betina dan ayam betina sudah bertelur atau memiliki rataan umur 7 bulan. Alat yang digunakan dalam penelitian adalah timbangan gantung untuk menimbang ayam. Jangka sorong dan pita ukur yang berfungi untuk mengukur ukuran tubuh ayam serta alat tulis. Penelitian dilakukan dengan menggunakan metode observasi dan penentuan sampel dengan cara purposive sampling. Proses penelitian diawali dari penelitian pendahuluan untuk mendapatkan ayam jantan dan betina yang disukai maupun yang tidak disukai. Metodenya dilakukan dengan metode observasi dengan cara melakukan wawancara dilakukan pada peternak ayam sebanyak 30 orang sebagai responden. Sifat kualitatif yang digunakan untuk membedakan ayam yang disukai dan tidak disukai adalah warna bulu, bentuk jengger, warna shank dan warna mata. Setelah mengetahui ciri-ciri ayam yang jantan dan betina yang disukai dan tidak disukai selanjutnya dilakukan survey lapangan untuk menentukan sifat kuantitatif untuk mengetahui morfometrik ayam kampung. Survey lapangan dilakukan dengan cara mengunjungi peternak 


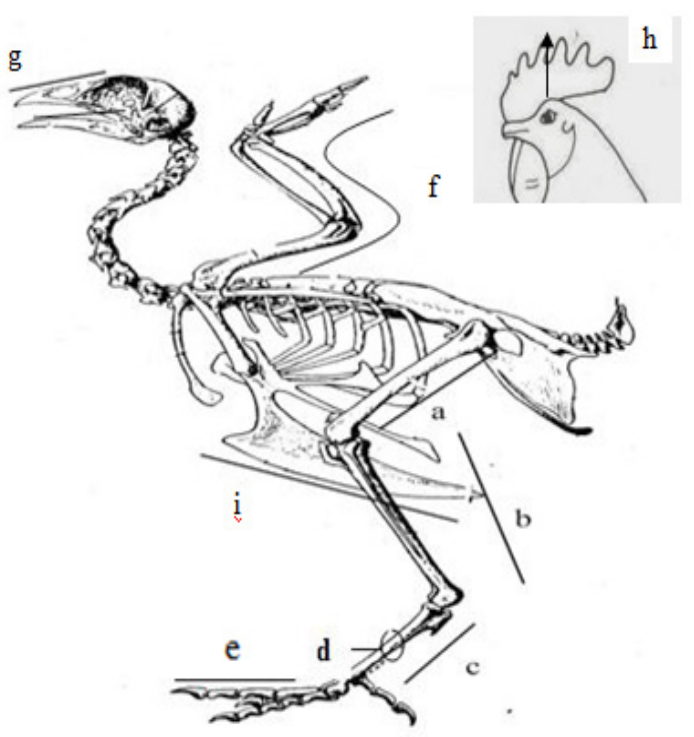

Gambar 1. Kerangka Tubuh Ayam (Sartika, 2013)

ayam, kemudian mennetukan sampel secara purposive sampling yaitu ayam yang disukai memiliki jengger single, warna shank dan mata kuning, warna bulu ayam jantan hitam kombinasi kuning sedangkan pada ayam betina memiliki warna bulu coklat hitam, putih totol hitam dan putih. Ayam yang tidak disukai masyarakat mempunyai ciri-ciri jengger pea, walnut dan rose, warna shank hitam, warna mata merah dan warna bulu hitam kombinasi merah pada ayam jantan sedangkan pada ayam betina memiliki warna bulu hitam dan abu-abu. Parameter yang diukur variabelnya terdiri dari 3 ekor ayam jantan yang disukai dan 2 ekor ayam jantan yang tidak disukai sedangkan ayam betina terdiri dari 56 ekor ayam yang disukai dan 44 ekor ayam yang tidak disukai. Parameter penelitian dilakukan pengukuran dengan metode pengukuran berdasarkan kerangka tubuh ayam (Sartika, 2013) pada Gambar 1 dan cara pengukurannya adalah:

a. Panjang paha atas diukur berdasarkan tulang femur $(\mathrm{cm})$ diukur pada sepanjang tulang paha pada bagian ujung distal yang berartikulasi dengan tibia, fibula, dan patella dengan menggunakan jangka sorong (Sartika, 2013; Suhardi, 2012).

b. Panjang paha bawah diukur berdasarkan tulang tibia $(\mathrm{cm})$ diukur dari patella sampai ujung tibia dengan meggunakan jangka sorong (Sartika, 2013; Suhardi, 2012).

c. Panjang kaki diukur berdasarkan tulang tarsometatarsus atau shank $(\mathrm{cm})$ diukur sepanjang tulang tarsometarsus dengan menggunakan jangka sorong.

d. Lingkar kaki diukur berdasarkan tulang tarsometatarsus (cm) diukur dengaan melingkari tulang tarsometarsus (shank) pada bagian tengah dengan menggunakan pita ukur yang kemudian dikonversi ke jangka sorong (Sartika, 2013; Suhardi 2012).

e. Panjang jari ketiga $(\mathrm{cm})$ diukur dari pangkal jari ketiga sampai ujung jari dengan menggunakan jangka sorong.

f. Panjang sayap (cm) diukur dengan merentangkan bagian sayap terlebih dahulu dan dimulai dari pangkal humerus sampai ujung phalanges dengan menggunakan pita ukur dan kemudian dikonversi ke jangka sorong.

g. Panjang maxilla $(\mathrm{cm})$ diukur dari pangkal sampai ujung paruh bagian atas dengan menggunakan jangka sorong (Sartika, 2013; Suhardi, 2012).

h. Tinggi jengger $(\mathrm{cm})$ diukur dari pangkal 
jengger di atas kepala sampai ujung jengger yang paling tinggi dengan menggunakan jangka sorong (Sartika, 2013; Suhardi, 2012).

i. Panjang dada diukur berdasarkan tulang sternum $(\mathrm{cm})$ diukur sepanjang tulang dada bagian depan mulai dari pangkal atas hingga ujung dada dengan menggunakan pita ukur kemudian dikonversi ke jangka sorong.

Analisis data karakteristik morfometrik antara ayam yang disukai dan tidak disukai oleh masyarakat dilakukan dengan cara perbandingan dengan uji t, kemudian dilanjutkan dengan Principal Component Analysis dan perhitungannya dilakukan dengan menggunakan alat bantu Statstical Analysis System (SAS) University Edition.

\section{HASIL DAN PEMBAHASAN}

\section{Sifat Kualitatif}

Penelitian pendahuluan dilakukan dengan menggunakan metode observasi wawancara dengan peternak sebanyak 30 sebagai responden yang digunakan untuk mengetahui ayam disukai dan tidak disukai. Hasil penelitian pendahuluan disajikan pada Tabel 1.

Bentuk jengger yang disukai oleh masyarakat Desa Tirtomulyo, Kecamatan Plantungan yang memiliki bentuk jengger single disukai 53,3\% responden, sedangkan jengger yang tidak disukai oleh masyarakat memiliki bentuk jengger pea, walnut dan rose dengan persentase masing-masing 33,3\%, $23,3 \%$ dan 26,7\% responden (Tabel 1). Tingkat kesukaan masyarakat pada bentuk jengger single dikarenakan bahwa masyarakat mayakini bahwa bentuk jengger single akan memiliki keturunan yang baik dan bagus apabila dikawinkan. Johari et al. (2009) menyatakan bahwa bentuk jengger single atau tunggal memiliki ciri-ciri berdiri tegak, pipih dan terbagi menyerupai gergaji sedangkan selama domestikasi saat ini menyebabkan terjadinya mutasi sehingga mengalami perubahan pada bentuk jengger sehingga terdapat bentuk mawar atau rose, kacang atau pea, walnut atau kemiri, berbentuk huruf $\mathrm{V}$ dan ada yang tidak berjengger.

Warna shank pada ayam kampung yang disukai adalah warna kuning dengan $76,7 \%$ responden sedangkan yang tidak disukai oleh masyarakat adalah warna hitam dengan $76,7 \%$ responden (Tabel 1). Ayam kampung yang mempunyai warna shank kuning lebih disukai masyarakat karena memiliki warna yang bersih. Warna shank yang berbeda disebabkan oleh adanya pigmen yang berbeda. Rusdin et al. (2011) menyatakan bahwa warna kuning pada shank dipengaruhi oleh tidak adanya pigmen melanin pada epidermis dan dermisnya tetapi terdapat pigmen karotenoid pada epidermisnya.

Warna mata yang disukai oleh warga adalah warna kuning dengan $83,3 \%$ responden sedangkan warna mata yang tidak disukai oleh masyarakat memiliki warna merah dengan $83,3 \%$ responden. Tingkat kesukaan masyarakat pada warna mata ayam yang berwarna kuning adalah mengindikasikan bahwa ayam tersebut sehat. Purwa (2007) menyatakan bahwa pada ayam petelur yang bagus harus memiliki bentuk mata yang bulat dan memiliki warna mata kuning kemerahan serta selaputnya yang bening jernih dan kering. Warna mata yang berbeda dipengaruhi oleh adanya pigmen yang terdapat pada ayam yang dapat mempengaruhi warna mata ayam yang berbeda. Gunnarsson et al. (2007) menyatakan bahwa anak ayam memiliki warna mata merah karena terdapat pigmen melanin yang akan bertambah gelap seiring bertambahnya umur.

Warna bulu ayam betina yang disukai memiliki warna bulu coklat hitam, putih totol hitam dan putih dengan persentase masingmasing $20 \%, 16,7 \%$ dan $46,7 \%$ responden sedangkan ayam betina yang tidak disukai memiliki warna bulu hitam dan abu-abu masing-masing $50 \%$ dan $23,3 \%$ responden (Tabel 1). Ayam jantan yang disukai memiliki bulu hitam kombinasi kuning dengan persentase $73,3 \%$ responden sedangkan warna 
Tabel 1. Hasil penelitian pendahuluan

\begin{tabular}{lcccc}
\hline \multirow{2}{*}{ Parameter } & \multicolumn{2}{c}{ Disukai } & \multicolumn{2}{c}{ Tidak Disukai } \\
\cline { 2 - 5 } Jengger & Jumlah & Persentase (\%) & Jumlah & Persentase (\%) \\
1. Single & 16 & 53,3 & 5 & 16,7 \\
2. Pea & 8 & 26,7 & 10 & 33,3 \\
3. Walnut & 3 & 10,0 & 7 & 23,3 \\
4. Rose & 3 & 10,0 & 8 & 26,7 \\
Warna Shank & & & & \\
1. Kuning & 23 & 76,7 & 7 & 23,3 \\
2. Hitam & 7 & 23,3 & 23 & 76,7 \\
Warna Mata & & & & \\
1. Kuning & 25 & 83,3 & 5 & 16,7 \\
2. Merah & 5 & 16,7 & 25 & 83,3 \\
Warna Bulu Ayam Betina & & & & \\
1. Coklat Hitam & 6 & 20,0 & 2 & 6,7 \\
2. Putih Totol Hitam & 5 & 16,7 & 3 & 10,0 \\
3. Putih & 14 & 46,7 & 3 & 10,0 \\
4. Hitam & 3 & 10,0 & 15 & 50,0 \\
5. Abu-abu & 2 & 6,6 & 7 & 23,3 \\
Warna Bulu Ayam Jantan & & & & \\
1. Hitam Kombinasi Kuning & 22 & 73,3 & 8 & 26,7 \\
2. Hitam Kombinasi Merah & 8 & 26,7 & 22 & 73,3 \\
\hline
\end{tabular}

bulu yang tidak disukai oleh masyarakat adalah ayam yang memiliki warna bulu hitam kombinasi merah dengan persentase $73,3 \%$ responden. Warna hitam kombinasi kuning pada ayam jantan lebih disukai oleh masyarakat karena harga jual yang tinggi pada ayam yang memiliki warna hitam sehingga ayam mempunyai keistimewaan yang terdapat pada warna bulu. Beragamnya warna bulu menyebabkan belum dapatnya merek dagang di pasar nasional maupun internasional. Rusdin et al. (2011) menyatakan bahwa beragamnya ayam yang berada di Indonesia menunjukkan bahwa masih tingginya heterozigot mengenai sifat-sifat yang dimiliki sehingga belum mendapatkan merek dagang di pasar nasional maupun global. Warna bulu pada ayam tidak berpengaruh terhadap produktifitas ayam akan tetapi memiliki nilai jual yang unggul. Mansjoer (2003) menyatakan bahwa warna bulu ayam tidak berhubungan erat terhadap produktifitas ayam, akan tetapi dalam sistem perdagangan akan memiliki nilai yang lebih unggul karena warna bulu akan menjadikan jaminan sebagai mutu kemurnian suatu jenis atau galur ayam.

Berdasarkan hasil penelitian pendahuluan materi yang digunakan untuk menentukan sifat kuantitatif adalah ayam jantan yang disukai sebanyak 3 ekor dengan ciri kualitatif jengger single, warna shank dan mata kuning, warna bulu ayam jantan hitam kombinasi kuning. Ayam jantan yang tidak disukai sebanyak 2 ekor dengan ciri kualitatif ciri jengger pea, walnut dan rose, warna shank hitam, warna mata merah dan warna bulu hitam kombinasi merah. Sampel ayam jantan hanya 3 ekor dan 2 ekor karena keterbatasan peternak memiliki ayam jantan. Ayam betina yang disukai sebanyak 56 ekor dengan ciri kualitatif memiliki jengger single, warna shank dan mata kuning, warna bulu coklat hitam, putih totol hitam dan putih. Ayam betina yang tidak disukai sebanyak 44 ekor 
JPI Vol. 22 (1): 11-20

Tabel 2. Rata-rata ukuran tubuh ayam kampung yang disukai dan tidak disukai oleh masyarakat pada kelompok jantan dan betina

\begin{tabular}{lrrrr}
\hline \multirow{2}{*}{ Parameter } & \multicolumn{2}{c}{ Jantan } & \multicolumn{2}{c}{ Betina } \\
\cline { 2 - 5 } & \multicolumn{1}{c}{ Disukai } & Tidak Disukai & \multicolumn{1}{c}{ Disukai } & Tidak Disukai \\
\hline Bobot Badan $(\mathrm{kg})$ & $2,10 \pm 0,08$ & $2,00 \pm 0,42$ & $1,38 \pm 0,25^{\mathrm{k}}$ & $1,26 \pm 0,31^{1}$ \\
Panjang Femur $(\mathrm{cm})$ & $10,76 \pm 0,47$ & $10,16 \pm 0,22$ & $9,00 \pm 0,66$ & $9,02 \pm 0,60$ \\
Panjang Tibia $(\mathrm{cm})$ & $14,11 \pm 1,01$ & $13,52 \pm 0,64$ & $11,99 \pm 0,73$ & $12,00 \pm 0,66$ \\
Panjang Tarsometarsus $(\mathrm{cm})$ & $8,90 \pm 0,83$ & $8,18 \pm 0,40$ & $7,28 \pm 0,76$ & $7,28 \pm 0,64$ \\
Lingkar Tarsometarsus $(\mathrm{cm})$ & $5,78 \pm 0,10^{\mathrm{a}}$ & $5,16 \pm 0,13^{\mathrm{b}}$ & $4,25 \pm 0,47$ & $4,14 \pm 0,34$ \\
Panjang Sayap $(\mathrm{cm})$ & $21,96 \pm 1,82$ & $22,27 \pm 0,14$ & $17,90 \pm 1,79$ & $17,89 \pm 1,27$ \\
Panjang Jari Ketiga $(\mathrm{cm})$ & $5,30 \pm 0,63$ & $5,20 \pm 0,05$ & $4,65 \pm 0,40$ & $4,66 \pm 0,43$ \\
Panjang Maxilla $(\mathrm{cm})$ & $2,69 \pm 0,15$ & $2,82 \pm 0,05$ & $2,05 \pm 0,36$ & $2,09 \pm 0,39$ \\
Tinggi Jengger $(\mathrm{cm})$ & $3,80 \pm 0,73$ & $4,22 \pm 1,38$ & $1,25 \pm 0,75^{\mathrm{k}}$ & $0,95 \pm 0,58^{1}$ \\
Panjang Sternum $(\mathrm{cm})$ & $11,34 \pm 0,42^{\mathrm{a}}$ & $9,92 \pm 0,35^{\mathrm{b}}$ & $9,55 \pm 0,62$ & $9,46 \pm 0,69$ \\
\hline Kenyyy
\end{tabular}

Keterangan: Superskrip yang berbeda antara ayam jantan dan betina yang disukai dengan tidak disukai pada baris yang sama menunjukkan perbedaan yang nyata $(\mathrm{P}<0,05)$

dengan cirri kualitatif jengger pea, walnut dan rose, warna shank hitam, warna mata merah, warna bulu hitam dan abu-abu.

\section{Sifat Kuantitatif}

Hasil penelitian sifat-sifat kuantitatif ukuran tubuh ayam kampung jantan dan betina yang disukai dan tidak disukai disajikan pada Tabel 2. Bobot badan ayam jantan disukai dan jantan tidak disukai oleh masyarakat menunjukkan tidak ada perbedaan yang nyata, sedangkan ayam betina yang disukai dan tidak disukai menunjukkan perbedaan yang nyata $(\mathrm{P}<0,05)$. Perbedaan yang nyata pada ayam betina disebabkan karena konsumsi pakan antara ternak satu dengan yang lain berbeda sedangkan tidak ada perbedaan yang nyata pada ayam jantan kemungkinan disebabkan oleh manajemen pakan. Untari et al. (2013) menyatakan bahwa pada bobot badan ayam kedu dapat dipengaruhi oleh manajemen pakan dan kesehatan ternak.. Rataan bobot badan ayam jantan yang disukai 2,10 $\pm 0,08$ $\mathrm{kg}$, sedangkan pada ayam jantan tidak disukai $2,00 \pm 0,42 \mathrm{~kg}$. Ayam betina disukai $1,38 \pm 0,25$ $\mathrm{kg}$ dan tidak disukai $1,26 \pm 0,31 \mathrm{~kg}$. Mansjoer (1985) menyatakan bahwa bobot badan ayam kampung dewasa mencapai 1,4 - 1,6 kg pada pemeliharaan secara tradisional.

Lingkar tarsometatarsus ayam jantan disukai dan tidak disukai menunjukkan perbedaan yang nyata $(P<0,05)$, sedangkan ayam betina disukai dan tidak disukai menunjukkan tidak ada perbedaan yang nyata. Rata-rata lingkar tarsometatarsus ayam kampung jantan yang disukai sebesar $5,78 \pm 0,10$ dan tidak disukai sebesar $5,16 \pm 0,13$ sedangkan ayam betina disukai $4,25 \pm 0,47$ dan tidak disukai 4,14 $\pm 0,34$. Penelitian Sitanggang et al. (2015) menyatakan bahwa ayam kampung memiliki lingkar shank sebesar 5,05 cm. Perbedaan lingkar tarsometatarsus dalam penelitian ini dapat disebabkan oleh lingkungan, sistem pemeliharaan dan manajemen pemeliharaan. Kusuma dan Prijono (2007) menyatakan bahwa bervariasinya ukuran tubuh ayam kampung dapat dipengaruhi oleh lingkungan pemeliharaan dan bibit yang berbeda.

Tinggi jengger ayam jantan disukai dan tidak disukai menunjukkan tidak ada perbedaan yang nyata sedangkan tinggi jengger ayam betina disukai dan tidak disukai menunjukkan perbedaan yang nyata $(\mathrm{P}<0,05)$. Rata-rata tinggi jengger ayam jantan disukai dan tidak disukai adalah $3,80 \pm 0,73 \mathrm{~cm}$ dan $4,22 \pm 1,38 \mathrm{~cm}$, sedangkan rata-rata tinggi jengger ayam betina disukai $1,25 \pm 0,75 \mathrm{~cm}$ dan tidak disukai $0,95 \pm 0,58 \mathrm{~cm}$. Ashifudin et al. (2017) menyatakan bahwa ayam kedu jengger 
Tabel 3. Hasil analisis principal component

\begin{tabular}{llcccc}
\hline \multirow{2}{*}{ No } & Parameter & \multicolumn{2}{c}{$\begin{array}{c}\text { Jantan Disukai dan Tidak } \\
\text { Disukai }\end{array}$} & \multicolumn{2}{c}{$\begin{array}{c}\text { Betina Disukai dan Tidak } \\
\text { Disukai }\end{array}$} \\
\cline { 3 - 6 } & & PC1 & PC2 & PC 1 & PC2 \\
\hline 1 & Panjang Femur & 0,168 & 0,192 & 0,248 & 0,216 \\
2 & Panjang Tibia & 0,476 & 0,162 & 0,167 & 0,453 \\
3 & Panjang Tarsometarsus & 0,390 & 0,234 & 0,145 & 0,587 \\
4 & Lingkar Tarsometarsus & 0,054 & 0,212 & 0,100 & 0,152 \\
5 & Panjang Sayap & 0,619 & $-0,581$ & 0,922 & $-0,304$ \\
6 & Panjang Jari Ketiga & 0,227 & $-0,023$ & $-0,031$ & 0,070 \\
7 & Panjang Maxilla & $-0,045$ & $-0,061$ & 0,096 & 0,051 \\
8 & Tinggi Jengger & $-0,385$ & $-0,309$ & $-0,055$ & 0,183 \\
9 & Panjang Sternum & 0,048 & 0,630 & 0,116 & 0,495 \\
\hline
\end{tabular}

Keterangan: $\mathrm{PC}=$ Principal Component

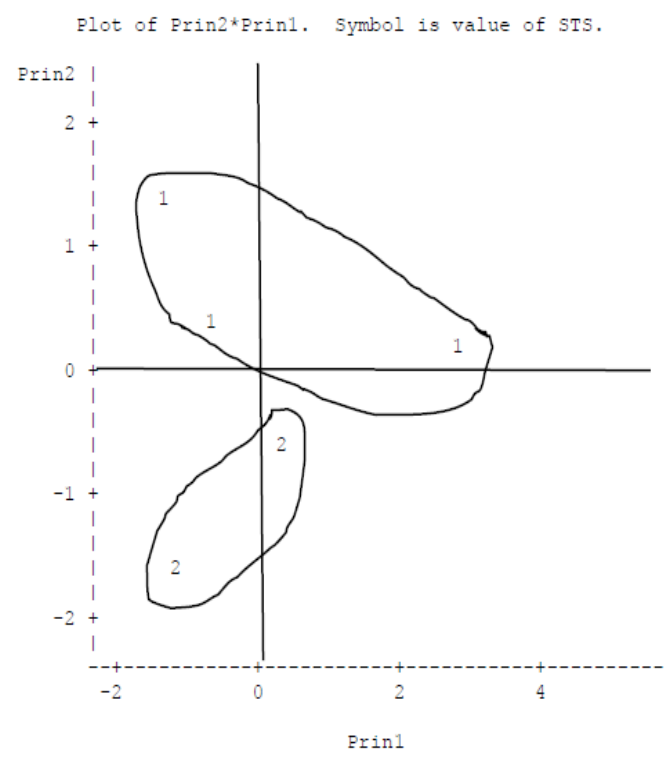

Gambar 2. Peta pengelompokan ayam kampung jantan

merah memiliki tinggi jengger $5,97 \mathrm{~cm}$ pada jantan dan 3,07 pada ayam betina, sedangkan ayam kedu jengger hitam jantan memiliki tinggi jengger $6,25 \mathrm{~cm}$ dan betina 2,39 $\mathrm{cm}$. Faktor yang mempengaruhi perbedaan ukuran tubuh dalam penelitian adalah faktor lingkungan. Menurut Hardjosubroto (1994) penampilan ukuran tubuh yang berbeda dapat dipengaruhi oleh faktor genetik serta lingkungan.

Panjang sternum ayam jantan disukai dan tidak disukai menunjukkan perbedaan yang nyata $(\mathrm{P}<0,05)$, sedangkan ayam betina disukai dan tidak disukai menunjukkan tidak ada perbedaan yang nyata. Perbedaan yang nyata pada ayam jantan disebabkan oleh perbedaan kecepatan pertumbuhan ternak satu dengan yang lain, sedangkan tidak ada perbedan yang nyata pada ternak betina dapat disebabkan oleh pertumbuhan tulang yang lambat. Jull (1978) menyatakan bahwa pertumbuhan tulang pada ayam jantan lebih cepat dibandingkan dengan pertumbuhan tulang pada ayam betina. Rata-rata panjang sternum ayam jantan disukai dan tidak disukai adalah $11,34 \pm 0,42 \mathrm{~cm}$ dan $9,92 \pm 0,35$ 


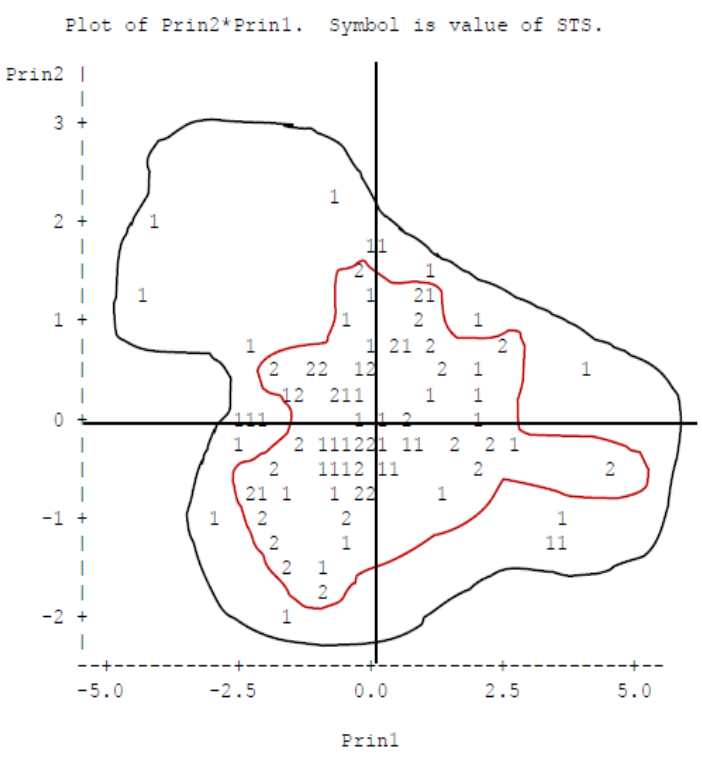

Gambar 3. Peta pengelompokan ayam kampung betina

$\mathrm{cm}$, sedangkan ayam betina disukai memiliki panjang sternum $9,55 \pm 0,62 \mathrm{~cm}$ dan tidak disukai 9,46 $\pm 0,69 \mathrm{~cm}$. Ashifuddin et al. (2017) menyatakan bahwa panjang sternum ayam jantan dan betina ayam kedu jengger hitam sebesar 13,30 $\mathrm{cm}$ dan 11,65 $\mathrm{cm}$ sedangkan panjang sternum ayam jantan dan betina ayam kedu jengger merah sebesar $13,29 \mathrm{~cm}$ dan $11,77 \mathrm{~cm}$.

\section{Parameter Pembeda Ayam Kampung yang Disukai dan Tidak Disukai pada Kelompok Jantan dan Betina}

Hasil analisis principal component antara ayam kampung jantan dan betina yang disukai dan tidak disukai oleh masyarakat disajikan pada Tabel 3.

Pada PC1 ayam jantan dan betina yang disukai dan tidak disukai menunjukkan bahwa panjang sayap memiliki nilai 0,619 dan 0,922 serta pada PC2 ayam jantan yang disukai dan tidak disukai panjang sternum memiliki angka yang tinggi yaitu 0,630 sedangkan pada ayam betina disukai dan tidak disukai panjang tarsometatarsus memiliki nilai yang tinggi yaitu 0,587 . Angka pada PC1 yaitu panjang sayap dapat dijadikan sebagai pembeda antara ayam jantan disukai dan tidak disukai serta ayam betina disukai dan tidak disukai.
Brahmantiyo et al. (2006) bahwa pada entok lokal dan entok impor panjang sayap dapat berpengaruh terhadap ukuran tubuh. Udeh and Ogbu (2011) menyatakan bahwa angka pada PC1 merupakan analisis komponen utama yang dijadikan sebagai acuan atau standar utama pembeda.

\section{Peta Pengelompokan Ayam Kampung yang Disukai dan Tidak Disukai pada Kelompok Jantan dan Betina}

Berdasarkan analisis komponen utama diperoleh hasil bahwa peta pengelompokan ayam jantan yang disukai berada pada kiri dan kanan daerah axis $\mathrm{Y}$ serta diatas axis $\mathrm{X}$ sedangkan ayam jantan tidak disukai berada di kanan dan kiri axis $\mathrm{Y}$ serta dibawah axis $\mathrm{X}$. Kelompok ayam betina disukai dan tidak disukai tersebar pada kanan dan kiri axis $\mathrm{Y}$ serta diatas dan dibawah daerah axis $\mathrm{X}$. Peta pengelompokan antar kelompok ayam kampung jantan dan betina disukai disajikan pada Gambar 2 dan 3.

Gambar 2 menunjukkan bahwa ayam kampung jantan disukai dan tidak disukai memiliki penyebaran yang tidak berhimpitan sehingga ayam kampung jantan disukai memiliki ukuran yang lebih besar dibandingkan ayam jantan yang tidak disukai. 
Gambar 3 menunjukkan ayam kampung betina disukai dan tidak disukai memiliki daerah penyebaran yang merata pada daerah axis $\mathrm{X}$ dan axis $\mathrm{Y}$ sehingga memiliki arti bahwa ayam kampung betina yang disukai memiliki ukuran tubuh yang lebih besar dibandingkan ayam betina yang tidak disukai. Brahmantiyo et al. (2003) menyatakan bahwa ternak dapat memiliki genetik yang sama hubungannya ditandai dengan peta penyebaran yang berhimpitan. Brahmantiyo et al. (2006) menyatakan bahwa terdapatnya kesamaan pada ternak dapat terjadi karena adanya persilangan yang dilakukan oleh peternak dengan menggabungkan beberapa bangsa yang bertujuan untuk mendapatkan sifat fisiologis yang dapat bertahan hidup didalam lingkungan tersebut.

\section{KESIMPULAN}

Parameter pembeda ayam jantan dan betina adalah panjang sayap. Peta pengelompokan menunjukkan ayam jantan dan betina yang disukai memiliki ukuran tubuh yang lebih besar dibandingkan ayam jantan dan betina yang tidak disukai.

\section{DAFTAR PUSTAKA}

Ashifudin, M., E. Kurnianto, dan Sutopo. 2017. Karakteristik morfometrik Ayam kedu Jengger Merah dan Jengger Hitam generasi pertama di Satker Ayam Maron-Temanggung. Jurnal Ilmu Ternak. 17 (1) : 40-46.

Brahmantiyo, B., L. H. Prasetyo, A. R. Setioko, dan R. H. Mulyono. 2003. Pendugaan jarak genetik dan faktor peubah pembeda galur itik (Alabio, Bali, khaki Campbell, Mojosari dan Pegagan) melalui analisis morfometrik. Jurnal Ilmu Ternak dan Veteriner. 8 (1) $: 1-7$.

Brahmantiyo, B., R. H. Mulyono, dan A. Sutisna. 2006. Ukuran dan bentuk itik pekin(Anasplatyrhynchos), entokimpor dan entok lokal (Cairina moschata). Lokakarya Nasional Pengelolaan dan Perlindungan Sumber Daya Genetik di Indonesia: Manfaat Ekonomi untuk Mewujudkan Ketahanan Nasional. Bogor, 20 Desember 2006. Balai Penelitian Ternak, Bogor. 266-272.

Gunnarsson, U., A. R. Hellstrom., M. T. Boichard., F. Minvielle., B. Bed'hom., S. Ito., P. Jensen., A. Rattink., A. Vereijken, and L. Andersson. 2007. Mutations in SLC45A2. Cause plumage color variation in chicken and Japanese quail. Genetics. 175 : 867-877.

Hardjosubroto, W. 1994. Aplikasi Pemuliabiakan Ternak di Lapangan. Gramedia, Jakarta.

Johari, S., Sutopo, dan A. Santi. 2009. Frekuensi fenotipik sifat-sifat kualitatif Ayam Kedu dewasa. Seminar Nasional Kebangkitan Peternakan. Semarang, 20 Mei 2009. Hal 606-616.

Jull, M. A. 1978. Poultry Husbandry $3^{\text {rd }}$ Ed. Mc. Graw-Hill Publishing Co. Ltd. New Delhi.

Kusuma, D. dan N. S. Prijono. 2007. Keanekaragaman Sumber Daya Hayati Ayam Lokal Indonesia : Manfaat dan Potensi . LIPI Press. Jakarta.

Mansjoer, S. S. 1985. Pengkajian Sifat-Sifat Produksi Ayam Kampung Beserta Persilangannya Dengan Rhode Island Red. Disertasi. Fakultas Pascasarjana Institut Pertanian Bogor.

Mansjoer, S. S. 2003. Potensi ayam buras di Indonesia. Makalah semiloka pengkajian pengembangan produksi bibit ayarn Buras dan Itik, CisaruaBogor, Tanggal 11 - 12 Desember 2003.

Purwa, D. R. 2007. Beternak ayam kampung petelur. Agromedia Pustaka. Jakarta.

Rahayu, B. W. I., A. E. P. Widodo, dan R. Sarunggalo. 2010. Penampilan pertumbuhan ayam persilangan Kampung dan Bangkok. Jurnal Ilmu Peternakan. 5 (2) : $77-81$. 
Rasyaf, M. 2011. Beternak Ayam Kampung. Penebar Swadaya, Jakarta.

Rusdin, M., L. O. Nafiu., T. Saili, dan A. S. Aku. 2011. Karakteristik fenotipe sifat kualitatif ayam tolaki di Kabupaten Konawe Sulawesi Tenggara. Agriplus Majalah Ilmiah. 21 (3) : 248-256.

Sadarman., Elfawati, dan Sadriadi. 2013. Studi frekuensi sifat kualitatif ayam kampung di Desa Menaming Kecamatan Rambah Kabupaen Rokan Hulu Provinsi Riau. Seminar Nasional Teknologi Peternakan dan Veteriner. Medan, 3-4 september 2013. Puslitbang Peternakan, Medan. 571-578.

Sartika, T. 2013. Perbandingan morfometrik ukuran tubuh Ayam KUB dan Sentul melalui pendekatan analisis diskriminan. Seminar Nasional Teknologi Peternakan dan Veteriner. Medan, 3-4 september 2013. Puslitbang Peternakan, Medan. 561-570.

Sitanggang, E. N., Hasnudi, dan Hamdan. 2015. Kergaman sifat kualitatif dan morfometrik antara ayam kampung, ayam Bangkok, ayam katai, ayam birma, ayam bagon dan magon di Medan. Jurnal Peternakan Integratif. 3 (2) : 167-189.

Suhardi, 2012. Identifikasi karakteristik morfologi ayam lokal khas dayak dari Kabupaten Berau, Kalimantan Timur. Jurnal Teknologi Pertanian 7 (2) : 8186.

Suryana dan A. Hasbianto. 2008. Usaha tani ayam buras di Indonesia: permasalahan dan tantangan. Jurnal Litbang Pertanian. 27(3) : $75-83$.

Udeh, I. and C. C. Ogbu. 2011. Principal component analysis of body measurements in three strainsof broiler chicken. Sci. World J. 6 (2): 11-14.

Untari, E. K., Ismoyowati, dan Sukardi. 2013. Perbedaan karakteristik tubuh Ayam Kedu yang dipelihara kelompok tani ternak "Makukuhan Mandiri" di Temanggung. 13 (2) : 135-145. 